\title{
Method of diffusive gradients in thin films (DGT) compared with other soil testing methods to predict phytoavailability of uranium and selected heavy metals from multipolluted soils
}

\author{
H. Vandenhove, J. Wannijn, L. Duquène and M.V. Hees \\ Belgian Nuclear Research Centre, Biosphere Impact Studies, 2400 Mol, Belgium
}

\begin{abstract}
The measurement of diffusive gradients in thin films (DGT) has been proposed as a surrogate for metal uptake by plants. A small-scale experiment was performed to test the predictive capacity of the DGT method with respect to uranium and heavy metal availability and uptake by ryegrass. Correlation analysis was performed to compare the results obtained with the DGT device with more conventional bioavailability indices: concentration in pore water or in selective extractants. Six soils with different histories of uranium contamination and with distinct soil characteristics were screened. For uranium, the bioavailability indices evaluated were highly correlated, indicating that uranium pools assessed were at least partially comparable. For heavy metals, bioavailability indices were hardly correlated. Uranium concentration in the pore water was a better predictor for uranium uptake than amount recovered following selective extraction. The concentration measured with DGT $\left(\mathrm{C}_{\mathrm{DGT}}\right)$ was also highly correlated with plant uptake. However, the significance level was sensitive to the value of the diffusion coefficient ( $\mathrm{pH}$ dependent or not) used to calculate $\mathrm{C}_{\mathrm{DGT}}$. For the heavy metals screened, only in the case of $\mathrm{Cd}$ was uptake predicted by $\mathrm{C}_{\mathrm{DGT}}$.
\end{abstract}

\section{INTRODUCTION}

In the assessment of the potential impact of contaminants in soils it is important to have an idea of the contaminant's mobility and bioavailability. Mobility and bioavailability of contaminants are among others affected by pollution type and origin, the element's physicochemical form and type and the physicochemical characteristics of the environment itself. Previous efforts to unravel the relation between 'available' forms of $U$ and availability for plant uptake have not been very promising [1-5]. A new approach to assess metal bioavailability in soils, the diffusive gradient in thin film (DGT) technique, was developed for sampling an available fraction of heavy metals in soils [6]. Several studies have demonstrated a significant linear relation between the DGT measured effective concentration and plant uptake of heavy metals [7-9].

The aim of this study was to test potential bioavailability indices for soils with different histories of uranium and heavy metal contamination and distinct soil characteristics and to evaluate whether one of these methods could be proposed as a quantitative measure of $\mathrm{U}$ and heavy metal bioavailability. Emphasis in this study is on U. The indices screened were: DGT measured concentrations, soil pore water concentration, fractions recovered following $0.4 \mathrm{M} \mathrm{MgCl}_{2}$ extraction (fraction considered exchangeable according to the NIST standardized sequential extraction method developed for $\mathrm{U}$ [10]) or $0.11 \mathrm{M} \mathrm{CH}_{3} \mathrm{COOH}$ extraction (fraction considered exchangeable according to the $\mathrm{BCR}$ sequential extraction method developed for heavy metal contaminated soils [11]).

\section{MATERIALS AND METHODS}

\subsection{Soil contamination history and soil analysis}

The six soils used covered a broad range of $\mathrm{pH}$, clay and organic matter content (Table 1) and had different histories of $\mathrm{U}$ contamination levels. Two soils were spiked with ${ }^{238} \mathrm{U}$ (acid and alkaline soil, 
Ac-Al). The Winterbeek soils (Agricultural and Natural, WA-WN) were impacted by effluents from the phosphate industry. The Settendorf soil (S) was impacted by U milling activities. The Bioul soil (B) has high natural background levels of $\mathrm{U}$. These latter 4 soils also contained higher concentrations of heavy metals. The heavy metals evaluated were $\mathrm{Cd}, \mathrm{Cr}, \mathrm{Cu}$ and $\mathrm{Zn}$. Soils were incubated (3 weeks, 50\% WHC) and analysed for $\mathrm{U}$ and heavy metal (HM) concentration in pore water, extractable U/HM $(0.4 \mathrm{M}$ $\mathrm{MgCl}_{2}$ or $0.11 \mathrm{M} \mathrm{CH}_{3} \mathrm{COOH}$ extracts), and U/HM recovered by the DGT resin ( $24 \mathrm{~h}$ deployment time). The mass of metals in the DGT resin gel $(\mathrm{M}, \mu \mathrm{g})$ was obtained following

$$
M=C_{e}\left(V_{\mathrm{HNO}_{3}}+V_{\mathrm{gel}}\right) / f_{e}
$$

where $\mathrm{C}_{\mathrm{e}}$ is the concentration in the eluent $\left(\mu \mathrm{g} \mathrm{ml}^{-1}\right), \mathrm{V}_{\mathrm{HNO}_{3}}$ is the volume of $\mathrm{HNO}_{3}(1 \mathrm{ml}), \mathrm{V}_{\mathrm{gel}}$ is the volume of gel $(0.15 \mathrm{ml})$ and $\mathrm{f}_{\mathrm{e}}$ is the elution factor for metals. For $\mathrm{f}_{\mathrm{e}}$ we applied a value of 0.678 for $\mathrm{U}$ as proposed by Li et al. [12] and a value of 0.8 as proposed by Zhang and Davison [6]. Time-averaged concentration at the soil interface diffusive layer was calculated from:

$$
C_{D G T}=\frac{M \Delta g}{D_{d} t A} 1000
$$

With $\Delta \mathrm{g}$ : diffusion layer thickness, $0.094 \mathrm{~cm} ; \mathrm{D}_{\mathrm{d}}$ : diffusion coefficient in the diffusion layer, $4 \cdot 10^{-6} \mathrm{~cm}^{2} \mathrm{~s}^{-1}$ for $\mathrm{U}$ [12] and 5.36, 3.00, 6.25 and $4.3810^{-6} \mathrm{~cm}^{2} \mathrm{~s}^{-1}$ for $\mathrm{Cd}, \mathrm{Cr}, \mathrm{Cu}$ and $\mathrm{Zn}$, respectively [13]; $t$ : deployment time, $s ; A$ : area of the gel membrane, $3.14 \mathrm{~cm}^{2}$. Li et al. [12] observed that $\mathrm{D}_{\mathrm{d}}$ for $\mathrm{U}$ decreased with increasing $\mathrm{pH}$. From their observations the following $\mathrm{pH}$-dependency of the $\mathrm{U}$ diffusion coefficient was derived: $\mathrm{D}_{\mathrm{d}, \mathrm{pH}}=-0.81 \mathrm{pH}+8.5\left(\mathrm{R}^{2}=0.97\right) . \mathrm{C}_{\mathrm{DGT}} \mathrm{pH}$ was therefore calculated using a $\mathrm{pH}$ dependent diffusion coefficient, $\mathrm{D}_{\mathrm{d}, \mathrm{pH}}$ (Table 1).

Analysis of $\mathrm{U}$ and heavy metals was done by ICP-MS. Distribution of aqueous uranium species was calculated using the geochemical computer code The Geochemist's Workbench®database Pro 5.04 [14] using the NEA thermodynamic data review by Grenthe et al. [15]. Speciation calculations were performed for the average soil solution composition.

\subsection{Plant culture and analysis}

Ryegrass was used as test plant. In total 24 containers were kept under greenhouse conditions $\left(20^{\circ} \mathrm{C} / 15^{\circ} \mathrm{C}, 12 \mathrm{~h} / 12 \mathrm{~h}, 260 \pm 30 \mu \mathrm{mol}\right.$ photons $\left.\mathrm{m}^{-2} \mathrm{~s}^{-1}\right)$. Shoots were harvested after 5 weeks plant growth. Dry weight was recorded and shoot $\mathrm{U}$ and heavy metal concentration analysed by ICP-MS.

\subsection{Statistics}

Correlation analysis were performed on log-transformed data with Statistica [16] for all U related parameters. For heavy metal related parameters analysis was done on original data.

\section{RESULTS AND DISCUSSION}

\subsection{Soil properties and $U$ availability}

General characteristics of the 6 soils are presented in Table 1. Total U content in soils ranged from $\sim 2 \mathrm{mg} \mathrm{kg}^{-1}$ for the Winterbeek soils to $157 \mathrm{mg} \mathrm{kg}^{-1}$ for the Settendorf soil. The soil with the largest U content (S) also showed the highest pore water concentration, and the soils with the smallest U content (WN and WA) showed the lowest pore water concentration. Total contents and concentration in soil solution hence seem well correlated $(r=0.94)$ despite the difference in contamination history and soil properties. However, the relation failed to be significant $(r=0.45)$ if the Settendorf soil (which clearly drives the regression) was excluded from the analysis.

Concentration of $\mathrm{U}$ in the soil solution $\left(\mathrm{C}_{\mathrm{sol}}\right)$ of spiked soils was higher than for soils with historical $\mathrm{U}$ contamination both in absolute and relative terms (except for the Settendorf soil), partially explained 
by the recent nature of the contamination. Higher $\mathrm{C}_{\mathrm{sol}}$ for the alkaline spiked soil compared to the acid spiked soil was explained by the formation of highly soluble carbonate complexes above $\mathrm{pH}$. The high amorphous iron content of the Winterbeek soils contributed to the low solubility. The Bioul soil showed the lowest $\mathrm{C}_{\mathrm{sol}}$ (relative) since $\mathrm{U}$ was largely incorporated in the mineral matrix. This soil also had a rather high $\mathrm{CEC}$, clay and amorphous $\mathrm{Fe}$ content and neutral $\mathrm{pH}$, contributing to lower U availability. High $\mathrm{C}_{\text {sol }}$ of the Settendorf soil could not be attributed to measured soil characteristics but speciation calculations showed the highest concentration of soluble uranylcarbonate species in this soil.

Table 1. Selected characteristics of the soils, total $U$ content $\left(\mathrm{C}_{\text {tot }}\right)$, concentration of uranium in the soil solution $\left(\mathrm{C}_{\mathrm{sol}}\right)$, extracted with $\mathrm{MgCl}_{2}\left(\mathrm{C}_{\mathrm{MgCl} 2}\right)$ or $\mathrm{CH}_{3} \mathrm{COOH}\left(\mathrm{C}_{\mathrm{AcA}}\right)$, DGT measured concentration calculated with constant diffusion coefficient $\mathrm{D}_{\mathrm{d}}\left(\mathrm{C}_{\mathrm{DGT}}\right)$ or $\mathrm{pH}$-dependent diffusion coefficient $\mathrm{D}_{\mathrm{d}, \mathrm{pH}}\left(\mathrm{C}_{\mathrm{DGT}, \mathrm{pH}}\right)$ and accumulation of $\mathrm{U}$ in shoots $\left(\mathrm{C}_{\text {shoot }}\right)$. Data represent mean and standard deviation (between brackets) $(\mathrm{n}=3)$.

\begin{tabular}{|l|l|l|l|l|l|l|l|}
\hline & & $\begin{array}{l}\text { Acid } \\
\text { soil }\end{array}$ & $\begin{array}{l}\text { Alkaline } \\
\text { soil }\end{array}$ & $\begin{array}{l}\text { Winterbeek } \\
\text { Agricultural }\end{array}$ & $\begin{array}{l}\text { Winterbeek } \\
\text { Natural }\end{array}$ & Bioul & Settendorf \\
\hline $\mathrm{pH}$ & $\mathrm{H}_{2} \mathrm{O}$ & $4.63(0.01)$ & $7.52(0.03)$ & $6.96(0.02)$ & $5.20(0.05)$ & $6.91(0.01)$ & $7.00(0.05)$ \\
$\mathrm{CEC}$ & $\mathrm{meq} \mathrm{kg}^{-1}$ & $51(5)$ & $240(1)$ & $302(34)$ & $516(34)$ & $332(16)$ & $219(25)$ \\
$\mathrm{Clay}$ & $\%$ & 4.5 & 201 & 4.2 & 3.2 & 13.5 & 18.8 \\
$\mathrm{OM}^{a}$ & $\%$ & 3.3 & 5 & 12.4 & 25.6 & 9.3 & 8 \\
$\mathrm{Amor}_{\mathrm{F}} \mathrm{Fe}^{\mathrm{b}}$ & $\mathrm{mg} \mathrm{kg}^{-1}$ & $2176(56)$ & $887(40)$ & $38214(557)$ & $81455(322)$ & $5116(44)$ & $4082(10)$ \\
\hline $\mathrm{C}_{\text {tot }}$ & $\mathrm{mg} \mathrm{kg}^{-1}$ & 34.9 & 361 & 2.2 & 1.8 & 46.8 & 156.9 \\
$\mathrm{C}_{\text {sol }}$ & $\mu \mathrm{g} \mathrm{L}^{-1}$ & $35.07(0.49)$ & $88.28(29.90)$ & $0.20(0.07)$ & $0.28(0.02)$ & $1.24(0.37)$ & $206.63(123.79)$ \\
$\mathrm{C}_{\mathrm{MgCl} 2}$ & $\mathrm{mg} \mathrm{kg}^{-1}$ & $0.67(0.02)$ & $2.96(0.28)$ & $0.008(0.000)$ & $0.018(0.000)$ & $0.030(0.003)$ & $0.21(0.01)$ \\
$\mathrm{C}_{\mathrm{AcA}}$ & $\mathrm{mg} \mathrm{kg}^{-1}$ & $3.93(0.12)$ & $1.85(0.04)$ & $0.008(0.004)$ & $0.004(0.000)$ & $0.107(0.008)$ & $4.41(0.35)$ \\
$\mathrm{C}_{\mathrm{DGT}}$ & $\mu \mathrm{g} \mathrm{L}^{-1}$ & $7.59(0.57)$ & $50.38(8.56)$ & $0.02(0.01)$ & $0.05(0.04)$ & $0.29(0.05)$ & $22.22(8.24)$ \\
$\mathrm{D}_{\mathrm{d}, \mathrm{pH}}$ & $10^{-6} \mathrm{~cm}^{2} \mathrm{~s}^{-1}$ & 4.7 & 2.4 & 2.8 & 4.3 & 2.9 & 2.8 \\
$\mathrm{C}_{\mathrm{DGT}, \mathrm{pH}}$ & $\mu \mathrm{g} \mathrm{L}^{-1}$ & $6.45(0.48)$ & $85.14(14.47)$ & $0.03(0.01)$ & $0.03(0.03)$ & $0.40(0.07)$ & $31.89(11.82)$ \\
\hline $\mathrm{C}_{\text {shoot }}$ & $\mu \mathrm{g} \mathrm{g}^{-1}$ & $0.14(0.05)$ & $2.36(0.24)$ & $0.02(0.01)$ & $0.013(0.008)$ & $0.022(0.002)$ & $3.43(0.01)$ \\
\hline
\end{tabular}

${ }^{\mathrm{a}} \mathrm{OM}=$ Organic Matter; ${ }^{\mathrm{b}}$ Amor. Fe: Amorphous Fe defined by oxalate extraction.

A similar picture was observed for $\mathrm{MgCl}_{2}$ and $\mathrm{CH}_{3} \mathrm{COOH}$ extractable amounts and for $\mathrm{C}_{\text {DGT }}$. Following log-transformation, significant correlations were found between $\mathrm{C}_{\text {sol }}$ and $\mathrm{U}$ recovered by the selective extractants $(r=0.96)$ and $\mathrm{C}_{\mathrm{DGT}}(\mathrm{r}=0.99)$. $\mathrm{C}_{\mathrm{DGT}}$ was also related to $\mathrm{U}$ recovered by the selective extractants $(\mathrm{r}=0.95)$. $\mathrm{C}_{\mathrm{DGT}, \mathrm{pH}}$ was significantly correlated with $\mathrm{C}_{\mathrm{sol}}$ but not with $\mathrm{U}$ recovered in the $\mathrm{MgCl}_{2}$ and $\mathrm{CH}_{3} \mathrm{COOH}$ extracts (Table 2).

$\mathrm{C}_{\mathrm{DGT}}$ was lower than $\mathrm{C}_{\mathrm{sol}}$ because of depletion of the soil solution concentration at the DGT interface. Lower values for $\mathrm{C}_{\mathrm{DGT}}$ than for $\mathrm{C}_{\mathrm{sol}}$ may be due since only a fraction of the $\mathrm{U}$ species in the soil solution are positively charged (DGT resin is negatively charged). Speciation calculations showed a predominance of neutral and negatively charged U species for soils with neutral-alkaline $\mathrm{pH}$. Only if neutral and negative charged complexes dissociate upon contact with the soil-DGT interface, uranyl can be sorbed by the resin. The higher $\mathrm{C}_{\mathrm{DGT}} / \mathrm{C}_{\text {sol }}$ ratio $(0.57)$ for the alkaline soil (with a predominance of negatively charged uranylcarbonate species), compared to that of the acid soil (0.22) (with a predominance of the free uranyl cation), implies a fast dissociation of negatively charged complexes, as found by Li et al. [12]. $\mathrm{C}_{\text {DGT }}$ was not significantly related to the concentration of free uranyl or positively charged U species (Table 2).

\subsection{Prediction of $U$ uptake from availability indices}

Concentration of $U$ in ryegrass shoots varied 300-fold (Table 1) and was highest for the spiked soils and the Settendorf soil, exhibiting high $U$ levels in soil solution and available fractions. $\mathrm{C}_{\text {sol }}$ and the $\mathrm{U}$ concentrations in ryegrass shoots were significantly correlated $(\mathrm{r}=0.95)$ (Figure 1a, Table 2). $\mathrm{C}_{\mathrm{DGT}}$ was a good predictor for $\mathrm{U}$ shoot uptake $\left(\mathrm{r}=0.94\right.$ ) (Figure $1 \mathrm{~b}$ ) only when $\mathrm{C}_{\text {DGT }}$ was calculated using 
Table 2. Correlation coefficients between $U$ availability indices and between $U$ availability indices and $U$ concentration in ryegrass shoots.

\begin{tabular}{|l|l|c|c|c|l|}
\hline & $\mathrm{C}_{\mathrm{sol}}$ & $\begin{array}{c}\mathrm{C}_{\mathrm{DGT}} \\
\mathrm{D}_{\mathrm{d}}=410^{-6} \mathrm{~cm}^{2} \mathrm{~s}^{-1}\end{array}$ & $\begin{array}{c}\mathrm{C}_{\mathrm{DGT}} \\
\mathrm{D}_{\mathrm{d}, \mathrm{pH}}\end{array}$ & $\mathrm{C}_{\mathrm{AcA}}$ & $\mathrm{C}_{\text {shoot }}$ \\
\hline $\mathrm{C}_{\mathrm{sol}}$ & & & & & $0.95^{* *}$ \\
\hline $\mathrm{C}_{\mathrm{DGT}:} \mathrm{D}_{\mathrm{d}}=410^{-6} \mathrm{~cm}^{2} \mathrm{~s}^{-1}$ & $0.99^{* * *}$ & & & & $0.94^{* *}$ \\
\hline $\mathrm{C}_{\mathrm{DGT}} \mathrm{D}_{\mathrm{d}, \mathrm{pH}}$ & $0.95^{* *}$ & & & & 0.45 \\
\hline $\mathrm{C}_{\mathrm{AcA}}$ & $0.96^{* *}$ & $0.95^{* *}$ & 0.64 & & $0.85^{*}$ \\
\hline $\mathrm{C}_{\mathrm{MgCl} 2}$ & $0.96^{* *}$ & $0.93^{* *}$ & $0.80^{+}$ & $0.95^{* *}$ & $0.84^{*}$ \\
\hline $\mathrm{U}_{2}^{++}$ & & 0.42 & 0.05 & & 0.23 \\
\hline Positively charged U species & & $0.77^{+}$ & 0.32 & & 0.61 \\
\hline
\end{tabular}

${ }^{+} \mathrm{p}<0.1 ;{ }^{*} \mathrm{p}<0.5 ;{ }^{* *} \mathrm{p}<0.01 ;{ }^{* * *} \mathrm{p}<0.001$.
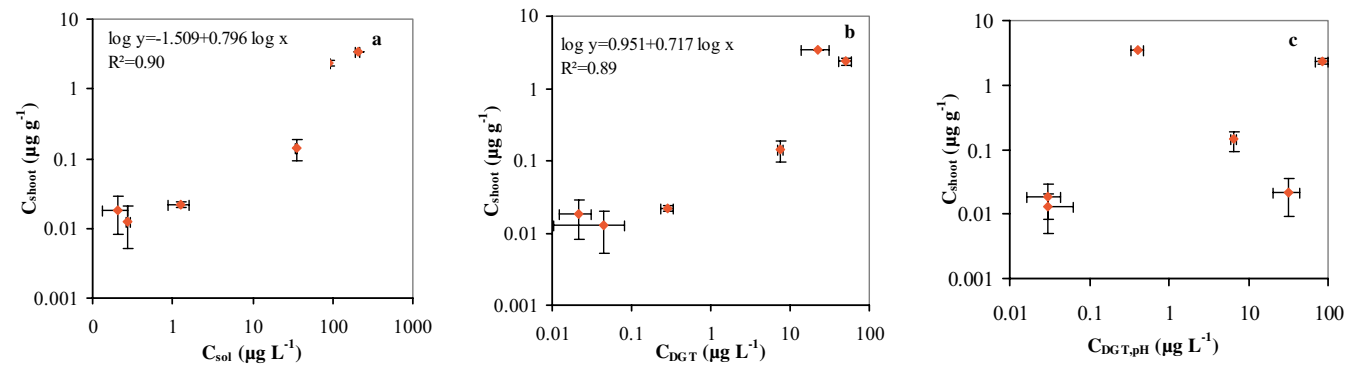

Figure 1. Relationship between $U$ concentration in ryegrass shoots $\left(C_{\text {shoots }}\right)$ and (a) $U$ concentration in the soil solution $\left(\mathrm{C}_{\text {sol }}\right)$; (b) DGT recovered concentration calculated with constant $\mathrm{D}_{\mathrm{d}}\left(\mathrm{C}_{\mathrm{DGT}}\right)$; (c) $\mathrm{pH}$ variable $\mathrm{D}_{\mathrm{d}, \mathrm{pH}}$ $\left(\mathrm{C}_{\mathrm{DGT}, \mathrm{pH}}\right)$.

a constant diffusion coefficient $\mathrm{D}_{\mathrm{d}}$. For $\mathrm{C}_{\mathrm{DGT}, \mathrm{pH}}$, this relationship was not significant (Figure 1c). This means that $\mathrm{C}_{\mathrm{DGT}}$ predictions are very sensitive to the value of the diffusion coefficient. Proper estimation of $\mathrm{D}_{\mathrm{d}}$ for $\mathrm{U}$ for conditions applicable to soils is hence required.

A significant correlation was found between $\mathrm{U}$ recovered in the $\mathrm{MgCl}_{2}$ or $\mathrm{CH}_{3} \mathrm{COOH}$ extracts and shoot concentration. This could also imply that the available fraction $\left(\mathrm{CH}_{3} \mathrm{COOH}\right.$ extraction $)$ defined by the BCR method developed for heavy metals is also useful for predicting U phytoavailability.

\subsection{Availability of heavy metals and prediction of heavy metal uptake from availability indices}

Contaminant levels are lowest for $\mathrm{Cd}$ and highest for $\mathrm{Cr}$ and $\mathrm{Zn}$. For a given element, there is an about factor 10 difference in total contaminant concentration and an about factor 100 difference in 'available' fractions between the different soils studied. DGT-recovered concentrations are low compared to pore water concentrations: the ration $\mathrm{C}_{\mathrm{DGT}} / \mathrm{C}_{\mathrm{sol}}$ is smaller than 0.3 except for $\mathrm{Zn}$ for Settendorf (0.6) and Winterbeek soils $(\sim 1.1)$ and for Cd for Bioul (0.5) and Winterbeek Agricultural soil (0.7) (Table 3).

Only few correlation coefficients between availability indices for heavy metals were significant (Table 4).

Predictability of shoot concentrations from availability indices was heavy metal dependent. Contrary to the results for $\mathrm{U}$, correlation was generally only significant with one availability index. Uptake of $\mathrm{Cd}$ by ryegrass was best predicted by pore water concentrations followed by $\mathrm{C}_{\mathrm{DGT}}$, whereas $\mathrm{Cr}$ and $\mathrm{Cu}$ uptake was best predicted by extraction with $\mathrm{MgCl}_{2}$, a methodology developed to assess $\mathrm{U}$ availability [10]. Shoot $\mathrm{Zn}$ concentrations could not be predicted by screened availability indices. No better correlations were obtained with concentration of free ions. 
Table 3. Total heavy metal content $\left(\mathrm{C}_{\mathrm{tot}}\right)$, concentration of heavy metals in the soil solution $\left(\mathrm{C}_{\mathrm{sol}}\right)$, extracted with $\mathrm{MgCl}_{2}\left(\mathrm{C}_{\mathrm{MgCl} 2}\right)$ or $\mathrm{CH}_{3} \mathrm{COOH}\left(\mathrm{C}_{\mathrm{AcA}}\right)$, DGT measured concentration $\left(\mathrm{C}_{\mathrm{DGT}}\right)$ and accumulation of heavy metals in shoots $\left(\mathrm{C}_{\text {shoot }}\right)$. Data represent mean and standard deviation (between brackets) $(n=3)$.

\begin{tabular}{|c|c|c|c|c|c|c|c|}
\hline & Soil & $\begin{array}{l}\mathrm{C}_{\text {tot }} \\
\mathrm{mg} \mathrm{kg}^{-1}\end{array}$ & $\begin{array}{l}\mathrm{C}_{\mathrm{sol}} \\
\mu \mathrm{g} \mathrm{L}^{-1}\end{array}$ & $\begin{array}{l}\mathrm{C}_{\mathrm{MgCl} 2} \\
\mathrm{mg} \mathrm{kg}^{-1}\end{array}$ & $\begin{array}{l}\mathrm{C}_{\mathrm{AcA}} \\
\mathrm{mg} \mathrm{kg}^{-1}\end{array}$ & $\begin{array}{l}\mathrm{C}_{\mathrm{DGT}} \\
\mu \mathrm{g} \mathrm{L}^{-1}\end{array}$ & $\begin{array}{l}\mathrm{C}_{\text {shoot }} \\
\mathrm{mg} \mathrm{kg}^{-1}\end{array}$ \\
\hline \multirow[t]{6}{*}{$\mathrm{Cd}$} & Winterbeek & 29 & $10.5(0.4)$ & $7.1(0.1)$ & $12.9(0.1)$ & $7.6(0.3)$ & $1.24(0.04)$ \\
\hline & Agricultural & & & & & & \\
\hline & Winterbeek & 13 & 279 (10) & $6.1(0.2)$ & $4.0(0.2)$ & $36(2)$ & $3.6(0.3)$ \\
\hline & Natural & & & & & & \\
\hline & Bioul & 2.3 & $1.6(0.2)$ & $0.92(0.01)$ & $0.87(0.03)$ & $0.8(0.1)$ & $1.1(0.5)$ \\
\hline & Settendorf & 9.9 & $263(35)$ & $7.4(0.1)$ & $9.0(0.3)$ & $30(3)$ & $3.5(0.4)$ \\
\hline \multirow[t]{6}{*}{$\mathrm{Cr}$} & Winterbeek & 1999 & $2.0(0.4)$ & $0.014(0.003)$ & $0.45(0.01)$ & $0.47(0.02)$ & $1.38(0.03)$ \\
\hline & Agricultural & & & & & & \\
\hline & Winterbeek & 774 & $2.9(0.3)$ & $0.029(0.003)$ & $0.10(0.01)$ & $0.3(0.1)$ & $2.4(0.1)$ \\
\hline & Natural & & & & & & \\
\hline & Bioul & 190 & $1.5(0.3)$ & $0.009(0.003)$ & $0.032(0.003)$ & $0.2(0.2)$ & $1.4(0.3)$ \\
\hline & Settendorf & 341 & $3.0(0.2)$ & $0.010(0.003)$ & $0.07(0.01)$ & $0.4(0.2)$ & $0.8(0.1)$ \\
\hline \multirow[t]{4}{*}{$\mathrm{Cu}$} & $\begin{array}{l}\text { Winterbeek } \\
\text { Agricultural }\end{array}$ & 125 & $55(5)$ & $2(1)$ & $4.8(0.8)$ & $10(1)$ & $5.5(0.9)$ \\
\hline & Winterbeek & 29 & $14.0(1.2)$ & $0.7(0.3)$ & $2(3)$ & $4(3)$ & $7.4(0.5)$ \\
\hline & $\begin{array}{l}\text { Natural } \\
\text { Bioul }\end{array}$ & 481 & $73(17)$ & $6(3)$ & $10.2(0.4)$ & $14.0(0.7)$ & $21.2(0.9)$ \\
\hline & Settendorf & 507 & $368(40)$ & $4.1(0.2)$ & $51(6)$ & $75(10)$ & $17.5(0.7)$ \\
\hline \multirow[t]{4}{*}{$\mathrm{Zn}$} & $\begin{array}{l}\text { Winterbeek } \\
\text { Agricultural }\end{array}$ & 1066 & $126(12)$ & $9(2)$ & $428(18)$ & $161(8)$ & $54(1)$ \\
\hline & $\begin{array}{l}\text { Winterbeek } \\
\text { Natural }\end{array}$ & 203 & 495 (14) & $9.1(0.4)$ & $44(9)$ & 572 (659) & $68(7)$ \\
\hline & Bioul & 345 & $105(32)$ & $3(2)$ & $17(2)$ & $33(21)$ & $68(4)$ \\
\hline & Settendorf & 1263 & $1851(115)$ & $71(1)$ & $445(5)$ & 1099 (157) & $239(4)$ \\
\hline
\end{tabular}

Table 4. Significant correlation coefficients between heavy metal availability indices (pore water concentration $\mathrm{C}_{\mathrm{sol}}$ correlated with related $\mathrm{C}_{\mathrm{DGT}}, \mathrm{C}_{\mathrm{AcA}}$ and $\mathrm{C}_{\mathrm{MgCl}}$ ) and between heavy metal availability indices and heavy metal concentrations in ryegrass shoots $\left(\mathrm{C}_{\text {shoot }}\right)$.

\begin{tabular}{|c|c|c|}
\hline $\mathrm{Cd}$ & $\begin{array}{c}\text { Correlation between } \\
\text { availability indices }\end{array}$ & $\begin{array}{c}\text { Correlation between availability } \\
\text { indices and } \mathrm{C}_{\text {shoot }}\end{array}$ \\
\hline $\mathrm{C}$ & $\begin{array}{c}\mathrm{C}_{\mathrm{sol}}-0.99^{* * *} \\
\mathrm{C}_{\mathrm{DGT}}-0.94^{* *}\end{array}$ \\
\hline $\mathrm{Cr}$ & $\mathrm{C}_{\mathrm{sol}}-\mathrm{C}_{\mathrm{MgCl} 2} 0.96^{* * *}$ & $\mathrm{C}_{\mathrm{MgCl} 2}-0.85+$ \\
\hline $\mathrm{Cu}$ & $\begin{array}{c}\mathrm{C}_{\mathrm{sol}}-\mathrm{C}_{\mathrm{DGT}} 0.94^{* *} \\
\mathrm{C}_{\mathrm{sol}}-\mathrm{C}_{\mathrm{AcA}} 0.91^{* *}\end{array}$ & $\mathrm{C}_{\mathrm{MgCl} 2}-0.92^{*}$ \\
\hline $\mathrm{Zn}$ & - & - \\
\hline
\end{tabular}

${ }^{+} \mathrm{p}<0.1 ;{ }^{*} \mathrm{p}<0.5 ;{ }^{* *} \mathrm{p}<0.01 ;{ }^{* * *} \mathrm{p}<0.001$.

Our results are not in agreement with literature findings, perhaps given the very diverse contamination history and characteristics of the soils studied or because of the limited data set. Koster et al. [17] found that DGT-measured $\mathrm{Zn}$, pore water content and $\mathrm{CaCl}_{2}$ extract, were all equally significantly related to Zn-uptake by lettuce and ryegrass. Zhang et al. [8] found that $\mathrm{Cu}$ uptake by Lepidium heterophyllum could be predicted more accurately from DGT measured fluxes than using total solution concentrations or even free ion pore water concentrations. Almås et al. [18] on the other hand found that the DGT measured concentration correlated well with the $\mathrm{Cd}$ and $\mathrm{Zn}$ uptake by spinach and ryegrass in the non-toxic range and the free ion concentration of $\mathrm{Cd}$ and $\mathrm{Zn}$ in pore water correlated well with the contents in spinach and ryegrass for a broader exposure range. 


\section{CONCLUSIONS}

The uranium bioavailability indices screened were highly correlated, indicating that uranium pools assessed were at least partially comparable. Uranium concentration in the pore water was a better predictor for uranium uptake by ryegrass than amount of uranium recovered following extraction with $0.11 \mathrm{M} \mathrm{CH}_{3} \mathrm{COOH}$ or $0.4 \mathrm{M} \mathrm{MgCl}_{2}$. The concentration measured with DGT concentration, $\mathrm{C}_{\mathrm{DGT}}$, was also highly correlated with plant uptake. However, the significance level was sensitive to the value of the diffusion coefficient ( $\mathrm{pH}$ dependent or not) used to calculate $\mathrm{C}_{\text {DGT }}$.

We also found a good relation between $\mathrm{U}$ recovered in the $\mathrm{MgCl}_{2}$ or $\mathrm{CH}_{3} \mathrm{COOH}$ extracts and ryegrass shoot concentrations. This could also imply that the BCR method developed for heavy metal sequential extraction, for which the first phase $\left(\mathrm{CH}_{3} \mathrm{COOH}\right.$ extraction $)$ is considered to be the available fraction, is also useful for predicting $\mathrm{U}$ phytoavailability. At sites contaminated with naturally occurring radionuclides, co-contamination with heavy metals generally occurs and, for these sites, a single extractant could hence suffice to assess (bio)availability of both natural radionuclides and heavy metals. However, the $\mathrm{CH}_{3} \mathrm{COOH}$ extracted concentrations did not predict shoot uptake of heavy metals under the conditions screened. For heavy metals, bioavailability indices were hardly correlated. In the case of $\mathrm{Cd}$ was ryegrass uptake predicted by total pore water concentration or $\mathrm{C}_{\mathrm{DGT}}$. and $\mathrm{Cr}$ and $\mathrm{Cu}$ uptake was correlated with $\mathrm{MgCl}_{2}$ extractable concentrations.

From the results obtained we could not conclude that the DGT method would have additional value in assessing uranium or heavy metal availability.

\section{References}

[1] Sheppard S.C. and Evenden W.G., Arch. Environ. Contam. Toxicol. 23 (1992) 117-124.

[2] Shahandeh H. and Hossner L.R., Soil Sci. 167 (2002) 269-280.

[3] Punshon T., Gaines K.F., Bertsch P.M. and Burger J., Environ. Toxicol. Chem. 22 (2003) 1146-1154.

[4] Vandenhove H., Van Hees M. , Wouters K. and Wannijn J., Environ. Pollut. 145 (2007) 587-595.

[5] Vandenhove, H., Van Hees M., Wannijn J., Wouters K. and Wang L., Environ. Pollut. 145 (2007) 577-586.

[6] Zhang H. and Davison B., Environ. Sci. Technol. 67 (1995) 3391-3400.

[7] Davison W., Hooda P.S., Zhang H. and Edwards A.C., Adv. Environ. Res., 3 (2000) 550-555.

[8] Zhang H., Zhao F.J., Sun B., Davison W. and McGrath S., Environ. Sci. Technol. 35 (2001) 2602-2607.

[9] Song J., Zhao F.-L., Luo Y.-M., McGrath S.P. and Zhang H., Environ. Pollut. 128 (2004) 307-315.

[10] Schultz M.K., Burnett W.C. and Inn K.G.W., J. Environ. Radioact. 40 (1998) 155-174.

[11] Rauret G., López-Sanchez J.F., Sahuquillo A., Rubio R., Davidson C., Ure A. and Quevaullier Ph., J. Environ. Monitor. 1 (1999) 57-61.

[12] Li W., Zhao J., Li C., Kiser S. and Cornett R.J., Anal. Chim. Acta 575 (2006) 274-280.

[13] Garmo Ø.A., Reyset O., Steinnes E. and Flaten T.P., Anal. Chem. 75 (2003) 3573-3580.

[14] Bethke C.M. The Geochemist's Workbench ${ }^{\circledR}$, Release 3.2., a User's Guide to Rxn, Act2, Tact, React and Gtplot. Hydrogeology Program. Urbana, IL, USA, University of Illinois, (2001).

[15] Grenthe I.J., Furger R.J.M., Konings R.J., Lemire A., Muller B., Nguy-en-Trung C. and Wanner H., Chemical thermodynamics of Uranium, Elsevier, Amsterdam, The Netherlands (1992).

[16] Statsoft, Inc. STATISTICA (Data analysis software system), version 6. www.stat.com (2004).

[17] Koster M., Reijnders L., van Oost N.R. and Peijnenburg W.J.G.M., Environ. Pollut. 133 (2005) 103-116.

[18] Almås Å.R., Lombnæs P., Sogn T.A. and Mulder J., Chemosphere (2006) 1647-1655. 